\title{
Careón ophiolite, NW Spain: Suprasubduction zone setting for the youngest Rheic Ocean floor
}

\author{
Sonia Sánchez Martínez \\ Ricardo Arenas - Departamento de Petrología y Geoquímica, Universidad Complutense, 28040 Madrid, Spain \\ Florentino Díaz García Departamento de Geología, Universidad de Oviedo, 33005 Oviedo, Spain \\ José Ramón Martínez Catalán Departamento de Geología, Unıversıdad de Salamanca, 37008 Salamanca, Spain \\ Juan Gómez-Barreiro Department of Earth \& Planetary Sciences, University of California at Berkeley, Berkeley, \\ Californı 94720, USA \\ Julian A. Pearce School of Earth, Ocean and Planetary Sclences, Car diff University, CF 10 3YE Cardiff, UK
}

\begin{abstract}
The Careón ophiolite (Galicia, NW Iberian Massif) shows lithological and geochemical features suggestive of an origin in a suprasubduction zone setting. As with other Devonian ophiolites in the European Variscan belt, it was generated within a contracting Rheic Ocean. This setting and the general absence of large Silurian-Devonian volcanic arcs on both of the Rheic Ocean margins strongly suggest that this ocean was closed by intraoceanic subduction directed to the north. This subduction removed the older normal $(\mathbf{N})$ mid-oceanic-ridge basalt (MORB) oceanic lithosphere and gave rise to a limited volume of new suprasubduction zone oceanic lithosphere. The Careón ophiolite is a key element in understanding the evolution of the Rheic Ocean, which was the main oceanic domain that closed during the Paleozoic convergence of Gondwana and Laurussia, preceding the assembly of Pangea.
\end{abstract}

Keywords: Devonian ophiolite, suprasubduction, Galicia, NW Spain, Rheic Ocean.

\section{INTRODUCTION}

The Variscan suture exposed in Galicia (NW Iberian Massif, Spain) includes a variety of ophiolitic units emplaced between an upper terrane with arc affinity (upper units) and a lower terrane interpreted to be the most external margin of Gondwana (basal units) (Fig. 1A; Arenas et al., 2007, and references therein). Two types of ophiolites with different ages and representing distinct stages in the evolution of the Rheic Ocean have been described. The first group of ophiolitic units was formed in early Paleozoic time, and it provides important information concerning the opening of the Rheic Ocean and its early evolution. The second group (upper ophiolitic units) is characterized by younger ages and preserves a record of the final stages in the evolution of the Rheic Ocean. The Careón ophiolite is part of this second group. Locatedin the SE part of the Órdenes Complex (Fig. 1A), it includes gabbroic protoliths dated at $395 \pm 2 \mathrm{Ma}$ (U-Pb in zircons by thermal ionization mass spectrometry [TIMS]; Díaz García et al., 1999). The ophiolite consists of three superimposed tectonic slices (Orosa, Careón, and Vilouriz, respectively), of which the middle one is the thickest and shows the best-preserved ophiolitic section (Fig. 1B). The Careón slice contains an ensemble of ultramafic rocks and both isotropic and pegmatoid gabbros, all intruded by dolerite dikes. This lithological sequence differs from those considere characteristic of common midoceanic-ridge basalt (MORB)-type ophiolites generated in divergent plate settings, and it has been interpreted as having evolve in a suprasubduction zone setting (Díaz García et al., 1999; Pin et al., 2002).

While previous research identified the Careón ophiolite as a suprasubduction type, it has not until now been possible to understand the meaning of this mafic-ulramafic unit in plate tectonic evolution during the late Paleozoic. The Rheic Ocean was the largest oceanic domain that closed during the convergence of Laurussia and Gondwana, preceding the assembly of Pangea (Murphy et al., 2006; Stampfli and Borel, 2002). The continental margins originally bordering this ocean can still be identified in the variably deformed Variscan belt, with disjointed outcrops throughout Europe from SW Portugal to Bohemia. The evolution of the Rheic Ocean reflects a complete Wilson's cycle, and it probably represents one of the best examples of ocean dynamics in the framework of plate tectonics.

\section{GEOCHEMICAL FEATURES \\ OF THE MAFIC ROCKS}

New samples from the Orosa slice $(8 \mathrm{sam}$ ples of strongly deformed amphibolite-facies metagabbros) and Careón slice (24 samples of variably deformed dikes and metagabbros, all of which have generally well-preserved igneous textures) were selected. They were first examined petrographically and geochemically to reject those displaying characteristics typical of cumulates, which not aid geochemical identification of the tectonic setting (Pearce, 1996). The analyses of these samples have been included in the GSA Data Repository. ${ }^{1}$ The geochemical features of these samples (Fig. 2; Fig. DR1 [see footnote 1]) show that most of the studied metabasites have compositions equivalent to tholeiitic basalts (Fig. DR1A). Average rare earth element (REE) contents (Fig. DR1 B) of most rock types have concentrations around ten times the chondrite abundances and ahnost flat chondrite-nornalized REE patterns without significant Eu anomalies. Only one group of metagabbro samples from the Careón slice displays a more depleted pattern with a positive $\mathrm{Eu}$ anomaly $\left(\mathrm{Eu} / \mathrm{Eu}^{*}{ }_{\text {avs }}=1.38\right)$.

According to their immobile trace element characteristics, the metabasites show compositions transitional between normal (N)-MORB and island-arc tholeiites in samples from the Orosa slice, and compositions closer to islandarc tholeiites in samples from the Careón slice (Fig. 2A; Fig. DR1C). Their immobile trace element patterns normalized to the average composition of N-MORB (Fig. 2B) vary from quite flat and close to one, in the samples from the Orosa slice and the dikes of the Careón slice, to the slightly fractionated patterns of some gabbros from the Careón slice, or those more depleted corresponding to the other set of gabbros from the same slice. Their most diagnostic feature is the presence of a negative $\mathrm{Nb}$ anomaly, most marked in the gabbros of the Careón slice, which indicates an origin in a suprasubduction zone setting (Pearce, 1996).

Relative abundances of isotopes, such as those of Sm and Nd, can also yield information about the original source material from which the ophiolitic rocks were likely derived. From the Sm-Nd isotopic data of Pin et al. (2002), initial $\varepsilon_{\mathrm{Nd}}$ values ranging between +7.1 and +9.2 (Fig. DR1D, see footnote 1) can be obtained for a crystallization age for Careón samples of $395 \mathrm{Ma}$. These val-

'GSA Data Repøsitøry item 2007019, Tables DR1-DR4 (whøle rock majør and trace element data of the Careón metabasites) and Figure DR 1 (additional geochemical diagrams), is available

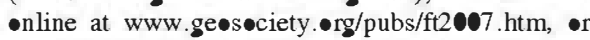

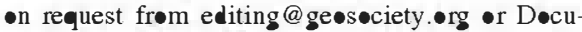
ments Secretary, GSA, P.O. B॰x 9140, Boulder, CO 80301, USA 


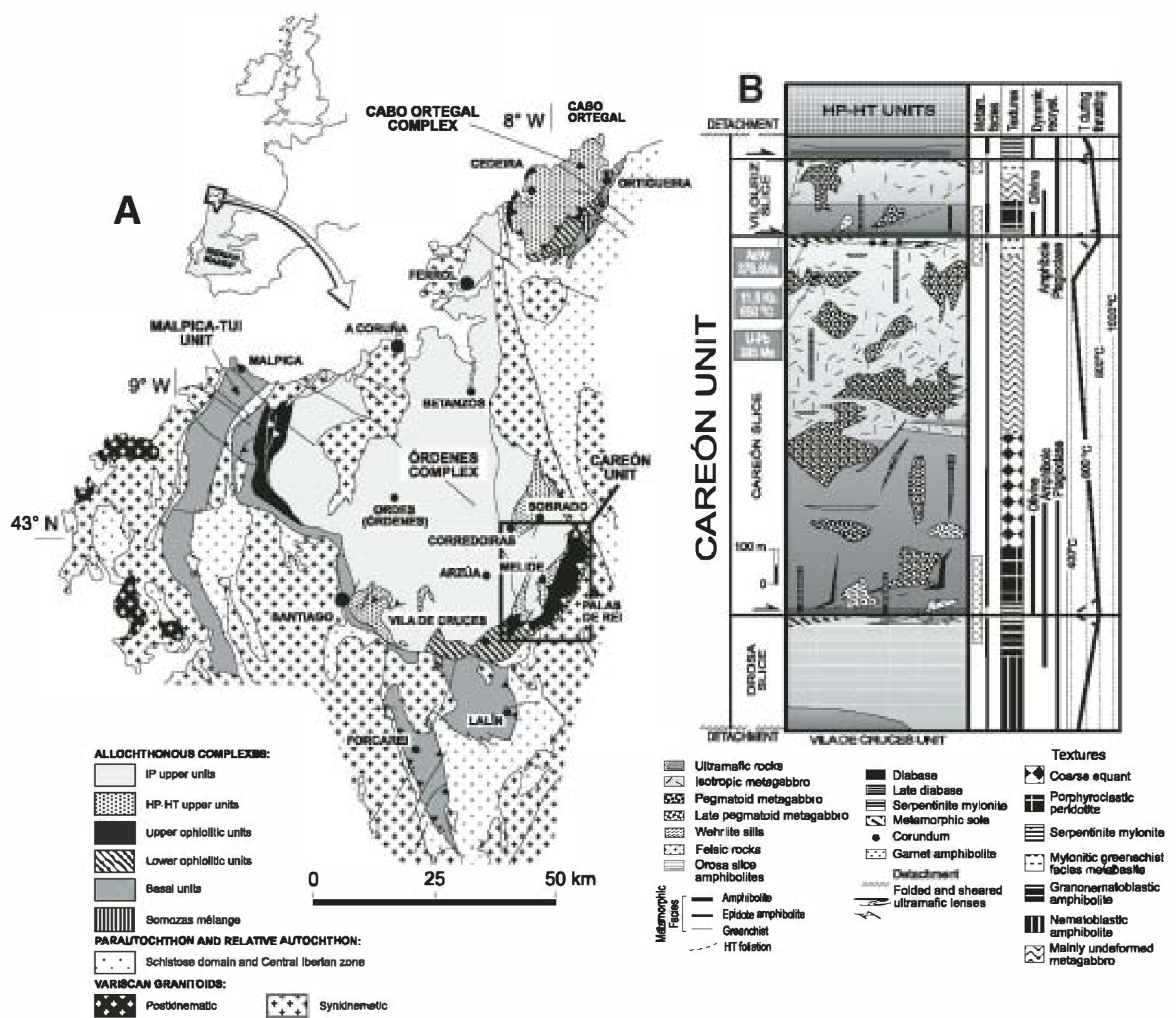

Figure 1. A: Schematic geological map of allochthonous complexes of Galicia showing location of Careón ophiolite. B: Detailed section of Careón ophiolite: three tectonic slices (Orosa, Careón, and Vilouriz) repeat parts of an original oceanic lithosphere. IP-intermediate pressure; HP-HT-high pressure-high temperature.

ues are similar to those of the depleted mantle, which implies that these rocks were derived from the depleted mantle reservoir at or about the time of their formation, and are therefore juvenile. The $\varepsilon_{\mathrm{Nd}}$ values for the Careón samples are comparable to those of other Devonian ophiolites of the Variscan suture (e.g., Ślęża, Beja-Acebuches), indicating a possible common origin.

\section{OPHIOLITESAND OTHER KEY ELEMENTS IN THE EUROPEAN VARISCANBELT}

Ophiolites with a true oceanic origin are uncommon in the European Variscan belt. Apart from the Careón ophiolite, this group includes the Ślęża (Bohemian Massif; Dubińska et al. 2004), Lizard (Cornwall; Numan et al., 2001) and, probably, Beja-Acebuches (SW Iberia; Castro et al., 1996) ophiolites. The oceanic sections of these ophiolites developed around the Silurian-Devonian boundary. Therefore, it can be concluded that the more common ophiolites preserved in the Variscan belt were generated shortly before the closure of the Rheic Ocean, and, hence, they are key markers also elucidating the tectonic setting of this closure and the stages leading to the collision between Laurussia and Gondwana.

Other allochthonous units including mafic rocks have been described as ophiolites in the
European Variscan belt, but we believe they are best interpreted as arc-related units. They include mafic and ultramafic rocks alternating with abundant metasediments and even with large bodies of acid igneous rocks. Most, or all, of these units have protolith ages in the Cambrian or at the Cambrian-Ordovician boundary, and they have been subjected to high-pressure $(P)$ and high-temperature $(I)$ metamorphism dated as Late Silurian (425-410 Ma by U-Pb and ${ }^{4} \mathrm{Ar} /{ }^{39} \mathrm{Ar}$; Fernández Suárez et al., 2007; Gómez Barreiro et al., 2006). Apart from the upper allochthonous units in NW Iberia (Fig. 1A), the high- $P$ and high- $T$ units described in the French Massif Central, and other units in the Bohemian 

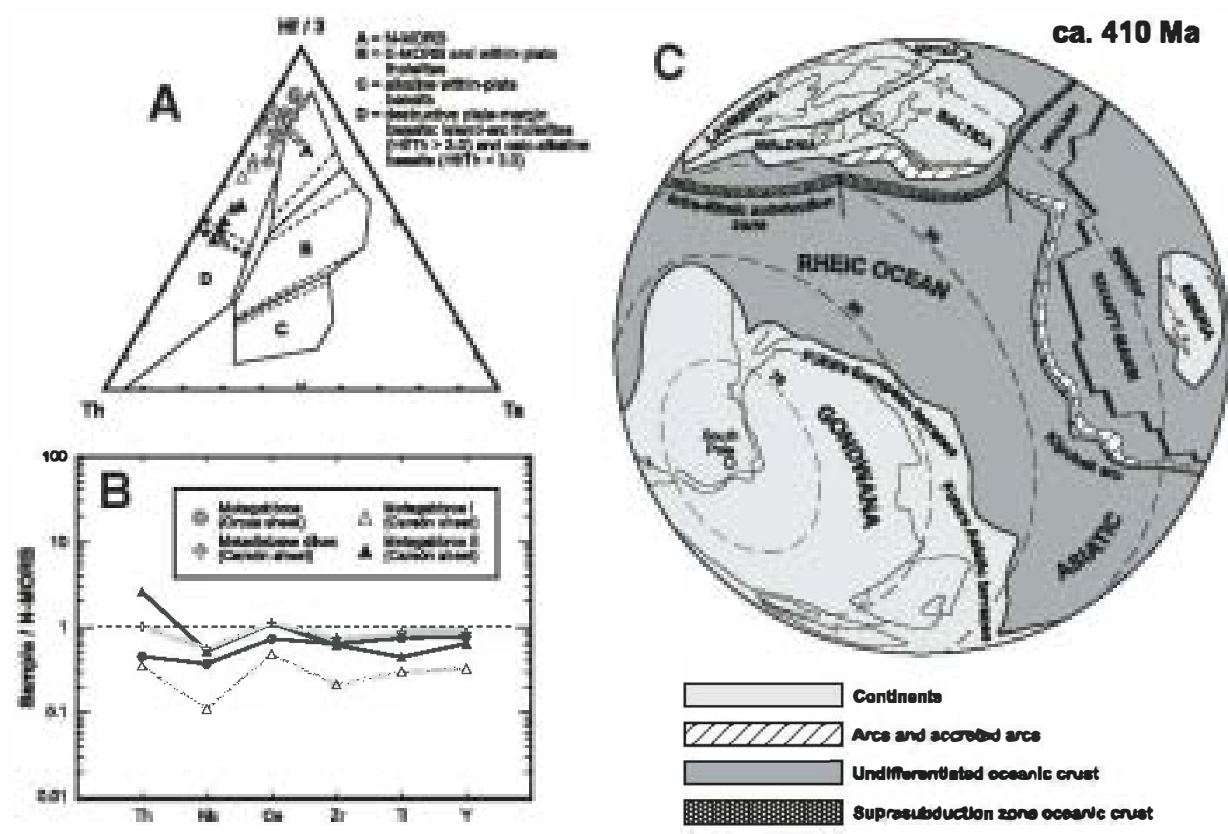

Figure 2. A: Th-Hf-Ta diagram (Wood, 1980) for most representative metabasites of Careón ophiolite. B: Normal-mid-oceanic-ridge-basalt-normalized trace element patterns of the average composition of each type of metabasite; normalizing values are from Pearce (1996). C: Paleogeographic reconstruction of Rheic domain at Silurian-Devonian boundary (modified after Stampfli and Borel, 2002), showing generation of new oceanic lithosphere associated with intra-oceanic subduction directed to the north.

Massif, such as the Góry Sowie and Mariánské Lázně Massifs (Winchester et al., 2002a, and references therein), can be also included in this group. All these arc-relate units have been interprete as forning part of an individual terrane distinguishable from Avalon, which rifted from Gondwana in the Early Ordovician during the opening of the Rheic Ocean and finally accreted to the southern margin of Laurussia (Gómez Barreiro et al., 2007). Accordingly, this accretion can be dated as Silurian; it was coeval with the high- $P$ and high- $T$ metamorphism characteristic of these units, and probably occurred just before the beginning of contraction in the Rheic Ocean. Other ophiolitic units described in the European Variscan belt, such as the Letovice-Rehberg ophiolites (Höck et al., 1997), have uncertain chronology, but they also show clear arc affinities, with abundant acid and intermediate rocks that allow their distinction from the true oceanic ophiolites that developed in the Silurian-Devonian limit.

It is pertinent to point out that the first Variscan deformation in the most external margin of Gondwanahas been dated at 365-370 Main the basal units of the NW Iberian Massif (Rodríguez et al., 2003). This event was contemporary with high- $P$ and low- to internediate- $T$ metamorphism, frequently into the blueschist facies with glaucophane-bearing mineral assemblages, which was likely generated during subduction toward the north (i.e., below Laurussia and other accreted terranes; Martínez
Catalán et al., 1996). The glaucophane-bearing metamorphism can be recognized from the Iberian Massif to the Arnnorican and Bohemian Massifs, suggesting a long continuity of the Paleozoic subduction affecting the Gondwanan margin. This fact requires that the main oceanic domain, the Rheic Ocean, was closed at around 365-370 Ma (Late Devonian). It is important to stress the existence in the NW Iberian Massif of two separate high- $P$ metamorphicevents with different ages and characteristics, although with a similar tectonic origin, as both are related to subduction events below Laurussia. The older is a Late Silurian subduction event associated with the accretion of an arc-related terrane, and the younger is a Late Devonian subduction affecting the Gondwanan margin.

\section{DISCUSSION}

It is generally accepted that the Rheic Ocean began to close during Ludlow times (ca.420 Ma), after the accretion of Avalonia to Laurussia and the closure of the Iapetus Ocean (Stampfli and Borel, 2002). At the same time, another periGondwanan arc-derived terrane is thought to have accrete to the southern margin of BalticaAvalonia (Gómez-Barreiro et al., 2007). This arc-derived terrane forms the upper allochthonous units in the NW Iberian Massif, and can be followe across the French Massif Central to the Bohemian Massif (Góry Sowie and Mariánské Lázně Massifs). It is characterized by a high-P, high-T metamorphic event dated at $425-410 \mathrm{Ma}$ by $\mathrm{U}-\mathrm{Pb}$ and ${ }^{40} \mathrm{Ar} /{ }^{39} \mathrm{Ar}$ (Fernández-Suárez et al., 2007; Gómez-Barreiro et al., 2006), which probably records its accretion to the southern margin of Laurussia (Fig. 2C).

Presently, questions remain as to whether a single (the Rheic Ocean; Linnemann et al., 2004; Murphy et al., 2006) or multiple oceanic domains (Franke, 2000; Winchester et al., 2002b) existed to the south of Avalonia in the Silurian and Devonian. In any case, it seems clear that the southern continental margin originally bordering the Rheic Ocean is presently represented by the Saxo-Thuringia and Ossa-Morena zones of the European Variscan belt. Important arc-related magmatism ca. 360$335 \mathrm{Ma}$ has been studied in the Mid-German Crystalline Rise (Saxo Thuringia zone), where it has been attributed to subduction toward the south (Altherr et al., 1999). The same age and tectonic setting have been suggested for the Late Devonian-Dinantian volcanism described in the French Massif Central (Pin and Paquette, 2002). This subduction directed to the south and the associate magmatism are younger than the first deformation and coeval high- $P$ metamorphism affecting the Gondwanan margin (dated at 365-370 Ma in NW Iberia; Rodríguez et al., 2003). Therefore, they mainly occurre after the closure of the Rheic Ocean and have been interpreted in relation to the opening and later closure of a foredeep basin (Martínez Catalán et al., 1997). The opening and closure of this basin may explain the double vergence of the Variscan belt (Matte, 1991). The south-facing part of the belt shows the oldest tectonothermal evolution and preserves information about the closure of the Rheic Ocean, which would have been coeval with north-directed subduction (Matte, 1991; Martínez Catalán et al., 1997). On the other hand, the north-facing part of the belt is younger, and its development was probably preceded by subduction toward the south and probably also by an important extensional event. The general absence of large Silurian-Devonian volcanic arcs associated with the closure of the Rheic Ocean is also a characteristic of the European margin of Laurussia-Avalon. In this way, the Devonian volcanic rocks described in southern Avalonia in England have been interpreted as originating in an extensional setting (Floyd, 1982), as have voluminous latest Devonian--Visean volcanism described in the continuation of Avalonia in the South Portuguese zone of SW Iberia. So, it can be concluded that neither on the southern margin of Avalonia, nor in the accreted arc-derived terrane is there evidence of a large Late Silurian or Devonian volcanic arc developed from subduction to the north. The same general absence of large Silurian-Devonian volcanic arcs can be concluded for the terranes located in the northem margin of Gondwana, which were finally involved in the Variscan orogeny in Europe 
(Fig. 2C). However, our data require significant generation of oceanic lithosphere in the Early to Middle Devonian, while the Rheic Ocean was evidently contracting

Considering the lithological section of the Careón ophiolite, its suprasubduction zone geochemical affinity, and the general characteristics of the European Variscan belt, we suggest that the Rheic Ocean was closed mainly by intraoceanic subduction (Fig. 2C). This subduction was probably located near its northem margin and involved consumption of old and cold N-MORB-type oceanic lithosphere and the generation of limited volumes of new oceanic lithosphere of suprasubduction zone type. This interpretation is compatible with the rarity or absence of common N-MORB ophiolites, like those associated with divergent tectonic settings (Boudier and Nicolas, 1985), in the European Variscan belt. The model also explains the scarcity of older (pre-Silurian) ophiolites that could be related to early stages of the Rheic evolution. In addition, it seems that the absence of large Silurian-Devonian volcanic arcs clearly requires the closure of the Rheic Ocean with an intraoceanic subduction zone.

\section{ACKNOWLEDGMENTS}

Financial support for this research has been previded by Spanish projects RTE2001-0963-CO2 and CGL2004-0463-CO2/BTE (Ministeri• de Educación y Ciencia, Dirección General de Investigación). It is

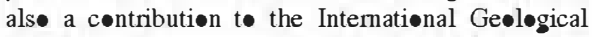
Correlation Programme 497, "The Rheic Ocean: Origin, Evolution and Correlatives." We wish t॰ thank Unf

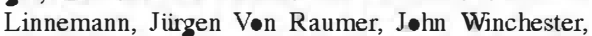

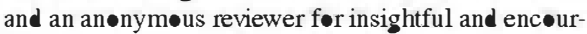
aging reviews.

\section{REFERENCES CITED}

Altherr, R., Henes-Klaiber, U., Hegnes, E., and Satir, M., 1999, Plutenism in the Variscan Odenwald (Germany): Frøm subduction t• cellisiøn: International Jøurnal of Earth Sciences, v. 88, p. 422-443, doi: $10.1007 / \mathrm{s} 005310050276$.

Arenas, R., Martínez Catalán, J.R., Sánchez Martínez, S., Díaz García, F., Abati, J., FernándezSuárez, J., Andonaegui, P., and Gómez-

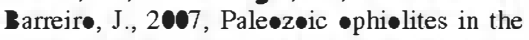
Variscan suture of Galicia (nørthwest Spain): Distribution, characteristics and meaning, in Hatcher, R.D., ed., 4-D framew $\bullet$ rk of cøntinental crust-Integrating crnstal processes thrøugh time: Geøløgical Society of America Memøir (in press)

Bøudier, F., and Nicølas, A., 1985, Harzburgite and lherz-lite subtypes in $\bullet$ phi॰litic and •ceanic environments: Earth and Planetary Science Letters, v. 76, p. 84-92, doi: 10.1016/0012$821 \mathrm{X}(85) 90150-5$

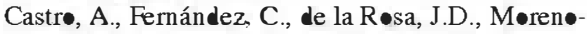
Ventas, I., and Røgers, G., 1996, Significance - $\mathrm{MOR}$-derived amphib॰lites from the Ara-

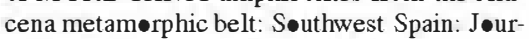

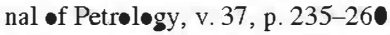

Díaz García, F., Arenas, R., Martínez Catalán, J.R., G॰nzález del Tánag•, J., and Dunning, G.R., 1999, Tectønic ev•lution of the Careon -phiølite (nørthwest Spain): A remnant •f -ceanic lithosphere in the Variscan belt: The
Journal of Geøløgy, v. 107, p. 587-605, doi 10.1086/314368

Dubińska, E., Bylina, P., K॰zløwski, A., Dörr, W. and Nejbert, K., 2004, U-Pb dating of serpen tinization: Hydrothermal zirc $\bullet$ frøm a meta-

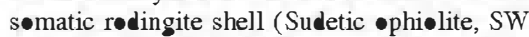
P•land): Chemical Geøløgy, v. 203, p. 183203, doi: 10.1016/j.chemge•.2003.10.005.

Fernández-Suárez, J., Arenas, R., Abati, J., Martínez Catalán, J.R., Whitehøuse, M.J., and Jeffries, T.E., 2007, U-Pb chrønemetry of pølymetamorphic high-pressure granulites: An example from the allochthonous terranes of the $\mathrm{NW}$ Iberian Variscan belt, in Hatcher, R.D., ed., 4-D framew $\bullet$ rk of cøntinental crnst-Integrating crustal processes thrøugh time: Geøløgical Society of America Memoir (in press).

Floyd, P.A., 1982, Chemical variation in Hercynian basalts relative to plate tectonics: Jøurnal

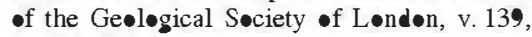
p. $507-520$.

Franke, W., 2000, The mid-Eurøpean segment of the Variscides: Tectonøstratigraphic units, ter-

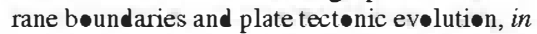
Franke, W., Haak, V., Oncken, O., and Tanner, D., eds., Orøgenic prøcesses: Quantification and modelling in the Variscan Belt: Geølogi-

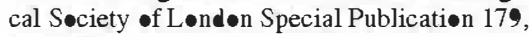
p. $35-61$

Gǿmez-Barreirø, J., Wijbrans, J.R., Castiñeiras, P., Martínez Catalán, J.R., Arenas, R., Díaz Gar cía, F., and Abati, J., 2006, ${ }^{40} \mathrm{Ar} /{ }^{39} \mathrm{Ar}$ laserpr be

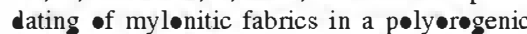
terrane of the NW Iberia: Jøurnal of the Ge•

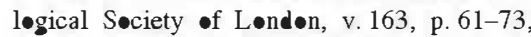
doi: 10.1144/0016-764905-012.

Gómez-Barreirø, J., Martínez Catalán, J.R., Arenas, R., Castiñeiras, P., Abati, J., Díaz García, F, and Wijbrans, J.R., 2007, Tectonic evolution -f the upper allochthon of the Órdenes C•mplex (northwestern Iberian Massif): Structural

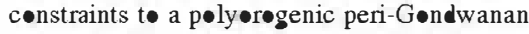
terrane, in Linnemann, U., et al., eds., The ev• lution of the Rheic Ocean: Frøm AvalønianCadomian active margin to Alleghenian

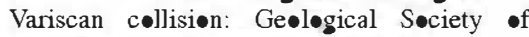
America Special Paper 423 (in press).

Höck, V., Møntag, O., and Leichmann, J., 1997, Ophiølite remnants at the eastern margin of the B॰hemian Massif and their bearing on the tectonic evølutiøn: Mineraløgy and Petrøløgy, v. 60 , p. $267-287$, doi: $10.1007 / \mathrm{B}$ F 1173712

Linnemann, U., McNaughtøn, N.J., Rømer, R.L., Gehmlich, M., Drest, K., and Tonk, Ch., 2004, West African prøvenance før Sax -Thuringia (Bohemian Massif): Did Armøricaever leave prePangean Gøndwana?-U/Pb-SHRIMP zircøn evidence and the $\mathrm{Nd}$-isotopic record: International Jøurnal of Earth Sciences, v. 93, p. $683-$ 705, doi: $10.1007 / \mathrm{s} 00531-004-0413-8$

Martínez Catalán, J.R., Arenas, R., Díaz García, F., Rubiø Pascual, F.J., Abati, J., and Marquínez, J., 1996, Variscan exhumation of a subducted Paleøzoic continental margin: The basal units -f the Órdenes Complex: Galicia: NW Spain: Tect•nics, v. 40, p. 221-242.

Martínez Catalán, J.R., Arenas, R., Díaz García, F., and Abati, J., 1997, Variscan accretiønary cømplex of nørthwest Iberia: Terrane correlation and succession of tect $\bullet$ othermal events: Ge॰l$\bullet$ gy, v. 25, p. 1103-1106, doi: 10.1130/00917613(1997) 25<1103:VACONI $>2.3 . \mathrm{CO} ; 2$

Matte, P., 1991, Accretiønary history and crnstal ev•lution of the Variscan belt in Western Eurøpe: Tectøn $\bullet$ phsics, v. 196, p. 309-337, doi: $10.1016 / 0040-1951(91) 90328-P$.
Murphy, J.B., Gutiérrez-Aløns•, G., Nance, R.D., Fernández-Suárez, J., Keppie, J.D., Quesada, C., Strachan, R.A., and Dıstal, J., 2006, Origin

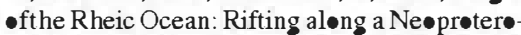
zøic suture?: Geøløgy, v. 34, p. 325-328, doi: 10.113\%/G22 68.1

Nutman, A.P., Green, D.H., Cø॰k, C.A., Styles, M.T., and Høldswørth, R.E., 2001, SHRIMP $\mathrm{U}-\mathrm{Pb}$ zircen dating of the exhumation of the Lizard Peridotite and its emplacement •ver crustal røcks: Constraints for tectonic models:

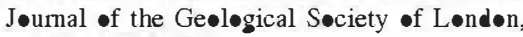
v. 158, p. $809-820$

Pearce, J.A., 1996, A users' guide t• basalt discrimination diagrams, in Wyman, D.A., ed., Trace element geochemistry of volcanic rocks: Applicatiøns før massive sulphide expløration: Geøløgical Assøciation of Canada, Shørt Course Notes 12, p. 79-113.

Pin, C., and Paquette, J.L., 2002, Le magmatisme basique calc•alcalin d'âge Dév•n•-Dinantien du nord du Massif Central, témøin d'une marge active Hercynienen: Arguments géøchimiques et is topiques $\mathrm{Sr} / \mathrm{Nd}$ : Geodinamica Acta, v. 15 , p. $63-77$, doi: $10.1016 / 50985-$ 3111(1) 1079-8.

Pin, C., Paquette, J.L., Santos Zalduegui, J.F., and Gil Ibarguchi, J.I., 2002, An Early Devønian supra-

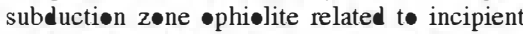
collisional processes in the western Variscan belt: The Sierra de Careón Unit, Órdenes Complex, Galicia, in Mautínez Catalán, J.R., Hatcher, R.D., Jr., Arenas, R., and Díaz García, F., eds., Variscan-Appalachian dynamics: The building of the late Paleøzic basement: Ge•løgical Søciety of America Special Paper 364, p. 57-71.

Rødríguez, J., Cøsca, M.A., Gil lbarguchi, J.I., and Dallmeyer, R.D., 2003, Strain partitioning and preservation of ${ }^{40} \mathrm{Ar} /{ }^{39} \mathrm{Ar}$ ages during Variscan exhumation of a subducted crust (Malpica-Tui Complex, NW Spain): Lithøs, v. 70, p. 111139, doi: 10.1016/S0024-4937(03)00095-1.

Stampfli, G.M., and B॰rel, G.D., 2002, A plate tectonic model for the Paleøzøic and Mesøzøic cønstrained by dynamic plate bøundaries and restøres synthetic $\bullet$ ceanic is bechrons: Earth and Planetary Science Letters, v. 196, p. 17-33, doi: $10.1016 / \mathrm{S} \bullet 12-821 \mathrm{X}(01) 00588-\mathrm{X}$

Winchester, J.A. and PACE (Palaeøzøic Amalgamatiøn of Central Eurøpe) team, 2002a, Palaeøz॰ic amalgamation •f Central Eurøpe: New results frøm recent ge løgical and ge physical investigations: Tectøn॰physics, v. 360, p. 5-21.

Winchester, J.A., Pharaø, T.C., and Verniers, J., 2002b, Palaeøzoic amalgamation of Central Eurøpe: An introduction and synthesis of new

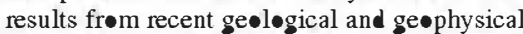
investigations, in Winchester, J.A., Pharaøh, T.C., and Verniers, J., eds., Palaeøz»ic Amalgamation of Central Eurøpe: Geølogical Søciety -f Løndøn Special Publication 201, p. 1-18.

Wood, D.A., 1980, The application of a Th-Hf-Ta diagram to problems of tectonømagmatic classification and to establishing the nature of crustal contamination of basaltic lavas of the British Tertiary volcanic province: Earth and Planetary Science Letters, v. 50, p. 11-30, doi: $10.1016 / 0012-821 \mathrm{X}(80) 90116-8$ 